Review

\title{
Cytokine-Modulating Strategies and Newer Cytokine Targets for Arthritis Therapy
}

\author{
Shivaprasad H. Venkatesha, Steven Dudics ${ }^{\dagger}$, Bodhraj Acharya ${ }^{\dagger}$ and Kamal D. Moudgil * \\ Department of Microbiology and Immunology, University of Maryland School of Medicine, \\ 685 W. Baltimore Street, HSF-1, Suite 380, Baltimore, MD 21201, USA; \\ E-Mails: hvshivaprasad@gmail.com (S.H.V.); sdudics1@gmail.com (S.D.); \\ bacharya@som.umaryland.edu (B.A.) \\ $\dagger$ These authors contributed equally to this work. \\ * Author to whom correspondence should be addressed; E-Mail: kmoud001@umaryland.edu; \\ Tel.: +1-410-706-7804; Fax: +1-410-706-2129.
}

Academic Editor: Bing Yan

Received: 10 November 2014 / Accepted: 25 December 2014 / Published: 31 December 2014

\begin{abstract}
Cytokines are the key mediators of inflammation in the course of autoimmune arthritis and other immune-mediated diseases. Uncontrolled production of the pro-inflammatory cytokines such as interferon- $\gamma$ (IFN- $\gamma$ ), tumor necrosis factor $\alpha$ (TNF $\alpha$ ), interleukin-6 (IL-6), and IL-17 can promote autoimmune pathology, whereas anti-inflammatory cytokines including IL-4, IL-10, and IL-27 can help control inflammation and tissue damage. The pro-inflammatory cytokines are the prime targets of the strategies to control rheumatoid arthritis (RA). For example, the neutralization of TNFa, either by engineered anti-cytokine antibodies or by soluble cytokine receptors as decoys, has proven successful in the treatment of RA. The activity of pro-inflammatory cytokines can also be downregulated either by using specific siRNA to inhibit the expression of a particular cytokine or by using small molecule inhibitors of cytokine signaling. Furthermore, the use of anti-inflammatory cytokines or cytokine antagonists delivered via gene therapy has proven to be an effective approach to regulate autoimmunity. Unexpectedly, under certain conditions, TNF $\alpha$, IFN- $\gamma$, and few other cytokines can display anti-inflammatory activities. Increasing awareness of this phenomenon might help develop appropriate regimens to harness or avoid this effect. Furthermore, the relatively newer cytokines such as IL-32, IL-34 and IL-35 are being investigated for their potential role in the pathogenesis and treatment of arthritis.
\end{abstract}


Keywords: autoimmunity; arthritis; biologics; cytokines; gene therapy; inflammation; interleukins; rheumatoid arthritis; siRNA

\section{Introduction}

Cytokines serve as the mediators of cellular differentiation, inflammation, immune pathology, and regulation of immune response. A balance between pro-inflammatory and anti-inflammatory cytokines is essential for the development of a well-regulated effector immune response. The overproduction of pro-inflammatory cytokines and/or the deficiency of anti-inflammatory cytokines may lead to immune pathology [1-5]. The classic, well-known pro-inflammatory cytokines include tumor necrosis factor $\alpha$ (TNF $\alpha$ ), interleukin-1 $\beta$ (IL-1 $\beta$ ), IL-6, interferon- $\gamma$ (IFN- $\gamma$ ) and IL-17 among others. TNF $\alpha$, IL-1 $\beta$ and IL-6 are mainly produced by cells of myeloid origin such as macrophages and dendritic cells, whereas, IFN- $\gamma$ and IL-17 are the defining cytokines for T helper 1 (Th1) and Th17 cells, respectively. Collectively, these pro-inflammatory cytokines, directly or indirectly, are involved in the differentiation and activation of pathogenic (e.g., Th17) cells, the migration of pathogenic cells into the target organ (the joints), the process of neovascularization (angiogenesis), the development and activation of osteoclasts, and the process of bone damage during the course of autoimmune arthritis $[1,5]$. On the other hand, the classic anti-inflammatory cytokines include IL-4 and IL-10, which display immunosuppressive activities. IL-23 and IL-27 represent additional cytokines of interest in rheumatoid arthritis (RA). IL-23 exerts pro-inflammatory activity with its ability to expand Th17 cells [6,7], whereas IL-27 acts as an anti-inflammatory cytokine in part via the inhibition of Th17 response [8,9]. The roles of most of the above-mentioned cytokines in the pathogenesis of RA are reviewed elsewhere by others and us [1-4], and are depicted in Figure 1. The salient features of three of the key pro-inflammatory cytokines (TNF $\alpha$, IL-6, and IL-17) involved in arthritis are summarized below.

$\mathrm{TNF} \alpha$ is produced primarily by macrophages but also can be produced by other cells, such as T cells, natural killer (NK) cells, mast cells and endothelial cells [10,11]. TNF $\alpha$ is released in large quantities when macrophages are exposed to lipopolysaccharide (LPS) or IL-1 $\beta$ [12]. TNF $\alpha$ is a member of the TNF superfamily [13]. The binding of TNFa to its receptor, the TNF receptor (TNFR) [14], can drive the cell to undergo apoptosis or activate the $\mathrm{NF}-\kappa \mathrm{B} /$ mitogen-activated protein kinase (MAPK) pathway. The latter pathway generates multiple mediators that participate in modulating apoptosis, cell survival, chemotactic migration of immune cells to the site of inflammation, and other inflammatory processes $[11,14,15]$. Neutralization of TNF $\alpha$ using either anti-TNF $\alpha$ antibodies or the soluble decoy receptor for TNF $\alpha$ has been instrumental in reducing the severity of arthritis, and a variety of biologics (e.g., infliximab, etanercept, etc.) based on this concept are currently being used in the clinic for the treatment of RA (Table 1). IL-17 is a critical pro-inflammatory cytokine in arthritis pathogenesis. Six members of the IL-17 family are named IL-17A-F. Among these, IL-17A has dominant role in the pathogenesis of RA. Th17 cells are the major source of IL-17A. The receptor complex consisting of IL-17RA and IL-17RC recognizes IL-17A and mediates downstream signaling events. These events in turn mediate upregulation of pro-inflammatory cytokines, chemokines, growth factors, and some enzymes of metabolic pathways, and alter oxidative status of the target organ. The impact of these 
events is manifest in the differentiation of naïve $T$ cells into pathogenic $T$ cells, the migration of pathogenic cells into the synovium, the increased survival of synoviocytes, angiogenesis, osteoclast differentiation and MMP secretion leading to bone and cartilage damage [16,17]. The expression of IL-17A is increased in inflammatory arthritis [16], and neutralization of IL-17A has been shown to reduce the severity of arthritis in the CIA model of RA [18]. Antibodies against IL-17 are currently being investigated in clinical trials for the treatment of RA (Table 1).

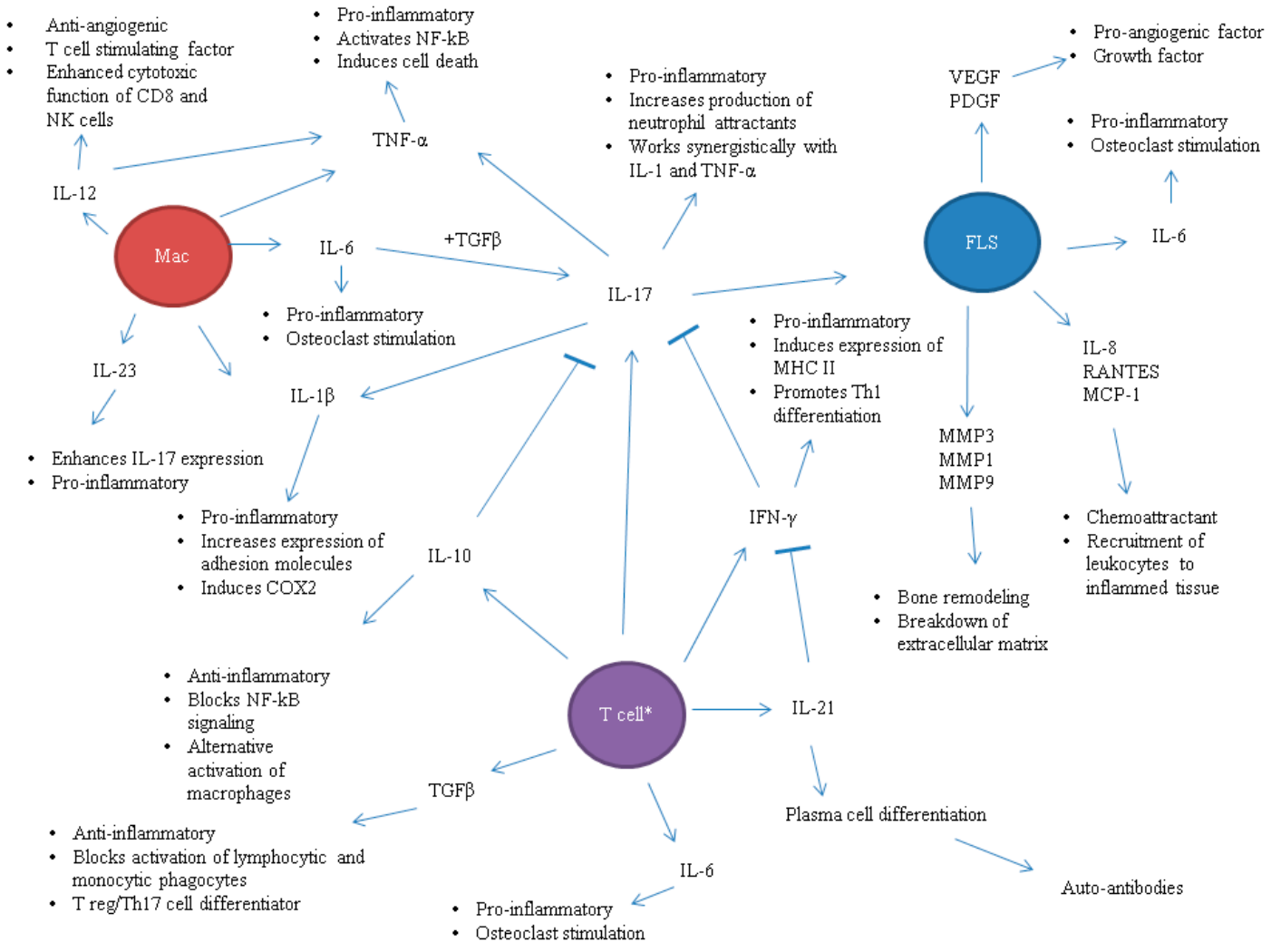

Figure 1. The roles of cytokines in arthritis pathogenesis. The cytokine environment in the joints and the draining lymphoid tissue in rheumatoid arthritis is rather complex. There are multiple cell types that are present and each secretes a panel of pro-/anti-inflammatory cytokines, chemokines, or other inflammatory mediators. Each cytokine has its own role in either promoting an immune response or regulating the immune response. Moreover, one cytokine can have more than one function, known as pleiotropy, or have duality of action (both pro- and anti-inflammatory properties). Furthermore, there is redundancy meaning that there are overlapping characteristics between different cytokines (e.g., IL-6 and IL-17 being pro-inflammatory). Depending on the proportion of cell types present within the joints and the type of immune stimuli that they are exposed to, the overall milieu in the tissue is predominantly pro-inflammatory or anti-inflammatory. COX2, cyclooxygenase type 2; FLS, fibroblast-like synoviocyte; IL, interleukin; Mac, macrophage; MCP-1, monocyte chemoattractant protein 1; MHCII, major histocompatability complex class II; MMP, matrix metalloprotease; PDGF, platelet derived growth factor; RANTES, regulated on activation, normal $\mathrm{T}$ cell expressed and secreted; TGF $\beta$, transforming growth factor $\beta$; Treg, T regulatory cell; VEGF, vascular endothelial growth factor. * Asterisk within the T cell denotes multiple subtypes: Th1, Th17, or Treg. 
Table 1. Examples of antibodies tested for the treatment of arthritis and other inflammatory/autoimmune diseases.

\begin{tabular}{|c|c|c|c|c|}
\hline Target & Agent & Type & Mechanism of Action & Ref. \\
\hline \multirow{6}{*}{ IL-1 } & Anakinra $^{\mathrm{a}}$ & Recombinant IL-1R $\alpha$ & Prevents binding of IL- $1 \beta$ to IL-1R $\alpha$ & [19] \\
\hline & Anti-IL-1 $\beta^{c}$ & $\begin{array}{l}\text { Human IgG1 monoclonal } \\
\text { antibody }(\mathrm{mAb})\end{array}$ & $\begin{array}{l}\text { Binds tightly to IL- } 1 \beta \text { and } \\
\text { neutralizes it }\end{array}$ & [20] \\
\hline & Canakinumab $^{\mathrm{b}}$ & Human IgG1 mAb & Neutralizes the activity of IL- $1 \beta$ & {$[21]$} \\
\hline & Gevokizumab $^{\text {b }}$ & Humanized IgG2 mAb & Neutralizes the activity of IL- $1 \beta$ & {$[22]$} \\
\hline & LY2189102 ${ }^{\mathrm{b}}$ & Humanized IgG4 mAb & Neutralizes the activity of IL- $1 \beta$ & [23] \\
\hline & Rilonacept ${ }^{\mathrm{b}}$ & $\begin{array}{l}\text { Ligand-binding domain of } \\
\text { IL-1RI and human IgG1 } \\
\text { fusion protein }\end{array}$ & $\begin{array}{l}\text { Attaches to and neutralizes } \\
\text { circulating IL-1 } \beta \text { before it can bind } \\
\text { its receptor }\end{array}$ & [24] \\
\hline \multirow{3}{*}{ IL-6 } & MAB406 ${ }^{\mathrm{c}}$ & $\mathrm{mAb}$ & Blocks IL-6 signaling & {$[25,26]$} \\
\hline & MRA $^{b}$ & Humanized $\mathrm{mAb}$ & Inhibits IL-6 signaling & {$[27]$} \\
\hline & Tocilizumab $^{\mathrm{a}}$ & Humanized $\mathrm{mAb}$ & $\begin{array}{l}\text { Binds to IL- } 6 \mathrm{R} \alpha \text { chain and blocks } \\
\text { IL- } 6 \text { signaling }\end{array}$ & {$[28,29]$} \\
\hline \multirow{4}{*}{$\mathrm{TNF} \alpha$} & Infliximab $^{\text {a }}$ & Recombinant IgG1 mAb & $\begin{array}{l}\text { Binds to TNF } \alpha \text { and prevents it from } \\
\text { binding to its receptor }\end{array}$ & {$[30,31]$} \\
\hline & Adalimumab $^{\mathrm{a}}$ & Recombinant IgG1 mAb & $\begin{array}{l}\text { Binds to TNF } \alpha \text { and prevents it from } \\
\text { activating TNF receptors }\end{array}$ & [32] \\
\hline & Etanercept $^{\mathrm{a}}$ & $\begin{array}{l}\text { Extracellular domain of } \\
\text { TNF receptor II (p75) and } \\
\text { the Fc portion of } \operatorname{IgG} 1 \\
\text { fusion protein }\end{array}$ & $\begin{array}{l}\text { Functions as a decoy receptor } \\
\text { to } \mathrm{TNF} \alpha\end{array}$ & [33] \\
\hline & Golimumab $^{\mathrm{b}}$ & Human $\mathrm{mAb}$ & Neutralizes TNF $\alpha$ bioactivity & [34] \\
\hline \multirow{3}{*}{ IL-17 } & Secukinumab $^{\mathrm{b}}$ & Human IgG1k mAb & $\begin{array}{l}\text { Selectively binds and } \\
\text { neutralizes IL-17A }\end{array}$ & {$[35,36]$} \\
\hline & Ixekizumab $^{\text {b }}$ & Humanized IgG4 mAb & Neutralizes IL-17A & [37] \\
\hline & Brodalumab $^{\mathrm{b}}$ & Human anti-IL17RA mAb & Inhibits the activity of IL-17 & [38] \\
\hline \multirow[t]{2}{*}{$\begin{array}{l}\text { IL-12/ } \\
\text { IL-23 }\end{array}$} & Ustekinumab $^{\mathrm{b}}$ & Human $\operatorname{IgG}_{1 \kappa} \mathrm{mAb}$ & $\begin{array}{l}\text { Blocks the biologic activity of IL- } 12 \\
\text { and IL-23 through their common p } 40 \\
\text { subunit by inhibiting their receptors }\end{array}$ & [39] \\
\hline & Guselkumab $^{\text {b }}$ & Human $\mathrm{mAb}$ & An IL-23p19-targeted mAb & {$[40]$} \\
\hline
\end{tabular}

The current status of these biologics is given as ${ }^{a}$ approved for treatment; ${ }^{b}$ completed or in clinical testing; and ${ }^{\mathrm{c}}$ completed or in preclinical testing.

IL-6 has significant implications in the development of arthritis [41]. IL-6 is mainly produced by dendritic cells and macrophages. IL-6 triggers signaling by binding to IL-6 receptor (IL-6R), which is expressed on some leukocytes. A soluble form of IL-6R exists in serum. The complex of IL-6 and IL-6R, or the complex of IL-6 and soluble IL-6R binds to gp130, leading to the activation of signaling cascade. IL-6 contributes to RA pathogenesis via multiple effector responses including the differentiation of Th17 cells, osteoclast differentiation through expression of RANKL, and production of other pro-inflammatory mediators and tissue-degrading enzymes [41,42]. Neutralizaton of IL-6 represents a promising therapy for RA and biologics based on IL- 6 are either currently being used for therapy or are in clinical testing (Table 1). 
Table 1 shows a panel of therapeutic agents that target the key pro-inflammatory cytokines in RA. These agents can be categorized into three groups. The first group of agents are those that are currently being used in the management of RA. The safety profile and efficacy of these agents has been duly validated leading to their regulatory approval for RA therapy. The second group of agents has either completed clinical testing or is currently being investigated in clinical trials. Following this step, additional efficacy and safety requirements may have to be met prior to their regulatory approval for RA therapy. The third group contains agents that have been tested in animal models of RA only, but have not yet moved on to clinical testing in RA patients. It is hoped that some of them will soon be ready for clinical testing. Taken together, there is a pipeline of potential therapeutic agents that will expand the pool of reliable drugs for RA patients in the near future.

In this article, we describe a variety of approaches used for modulation of cytokine responses to control arthritis (Figure 2, Tables 1 and 2) and the properties of relatively newer cytokines (IL-32, IL-34, and IL-35), which have shown association with RA pathology and are being tested for their use in arthritis therapy in experimental models of RA.

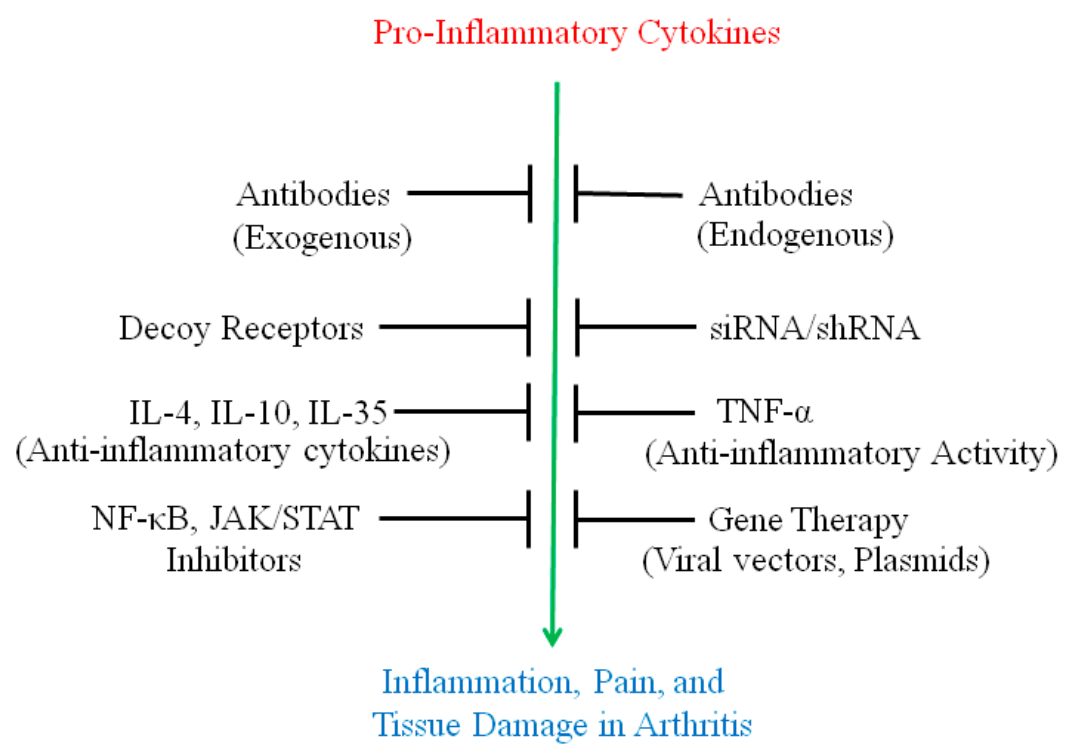

Figure 2. Diverse strategies employed to control the activity of pro-inflammatory cytokines and tissue damage. Pro-inflammatory cytokines, when produced in excess, can cause significant damage to tissues in various autoimmune diseases. Multiple approaches have been developed to prevent and ameliorate the harmful side effects of the pro-inflammatory cytokines. Anti-cytokine antibodies can inhibit the binding of the cytokines to their receptors. Decoy receptors can similarly bind the cytokines and prevent them from binding to the corresponding natural receptors on the cell surface. Gene therapy can be used to suppress the production of specific pro-inflammatory cytokines, whereas siRNAs can silence particular mRNA that encode the cytokine and thereby, prevent its production. Small molecule inhibitors can target certain pathways involved in the production of pro-inflammatory cytokines as well as inhibit their signaling abilities. Finally, anti-inflammatory cytokines help downregulate the pathogenic immune responses and subsequently inhibit further tissue damage. Paradoxically, TNF $\alpha$ can display anti-inflammatory properties under certain conditions. 
Table 2. Cytokine modulation by gene therapy for arthritis therapy.

\begin{tabular}{ccccc}
\hline Target Cytokine & Vector & Mode of Gene Transfer & Model & Ref. \\
\hline \multirow{2}{*}{ IL-1 $\beta$} & rAAV-IL-1Ra & In vivo & Mouse & {$[43]$} \\
& IL-1Ra Gene & Ex vivo & Human & {$[44]$} \\
& MFG-IRAP & Ex vivo modified Fibroblast & Human & {$[45]$} \\
\hline \multirow{2}{*}{ TNF- $\alpha$} & sTNFR plasmid electrotransfer & In vivo & Mouse & {$[46,47]$} \\
& AAV-TNF- $\alpha$ & Locally into joints & Human & {$[48]$} \\
\hline IFN- $\beta$ & Adenovirus vector & Intra-articular & Rat & {$[49]$} \\
\hline IL-4 & Adenoviral vector & In vivo & Mouse & {$[50]$} \\
\hline \multirow{2}{*}{ IL-10 } & Lentivirus using inflammation & & & \\
& promoter switches Saa3 and & Intra-articular & Mouse & {$[51]$} \\
& Mmp13 & & & \\
\hline IL-18 & Adenoviral vector & In vivo & Mouse & {$[52]$} \\
\hline
\end{tabular}

\section{Use of Antibodies and Decoy Receptors against Pro-Inflammatory Cytokines/Cytokine Receptors for the Treatment of Arthritis}

A comprehensive understanding of the role of cytokines in the pathogenesis of RA has led to the development of new therapeutic approaches aimed at specifically neutralizing the cytokine or inhibiting cytokine signaling pathways. Unlike generalized immunosuppression, selective targeting of a particular pathogenic cytokine offers a distinct advantage for the treatment of RA and some other autoimmune diseases. The main target cytokines of interest for the treatment of RA are: TNF $\alpha$, IL-1 $\beta$, IL-6, IL-17, and IL-23 [1,5,53,54]. Inhibition of the activity of some of these cytokines has yielded promising results in studies on animal models of RA and in clinical trials in patients with RA [5,55]. Various biologics that target cytokines or cytokine receptors are comprised of specifically engineered (e.g., humanized) monoclonal antibodies, soluble recombinant cytokine receptors, and fusion-proteins containing the cytokine binding domain and the Fc portion of human IgG1. The nature and mechanisms of actions of different biologics that have been used for the treatment of RA and some other autoimmune diseases are summarized in Table 1.

Although efficacious, the above-mentioned biologics have some limitations [55-58]. These include the unresponsiveness of a proportion of patients to the therapeutic agent; the short-lived effect necessitating frequent injections of the biologic; gradual loss of sensitivity to the therapeutic agent with time; the likelihood of disease exacerbation (flares) if therapy is stopped for a long time; the high cost; and the increased risk of infections because of systemic immunosuppression. Given the limitations of anti-TNF $\alpha$ and anti-IL-1 $\beta$ therapy, continued efforts are directed towards targeting other cytokines (e.g., IL-6 and IL-17). Contrary to the expectation that perhaps combination therapy with different biologics might offer an advantage over a single agent, such an approach was found to impair the host defense without offering any additional advantage to RA patients [59].

Paradoxically, TNF $\alpha$, which represents a prototypic pro-inflammatory mediator, can exhibit anti-inflammatory effects under certain conditions. For example, TNF $\alpha$ has been shown to suppress inflammation in rat AA, an experimental model of RA [60,61]. When Lewis (LEW) rats were immunized with heat-killed Mycobacterium tuberculosis (Mtb) for disease induction and then subsequently injected with TNF $\alpha$ i.p., these rats, when compared to controls, displayed a significant 
decrease in the severity of AA. Also, the amount of IFN- $\gamma$ secreted in response to the pathogenic determinant of the disease-related antigen, mycobacterial heat-shock protein 65 (Bhsp65), was also lower in the TNF $\alpha$-treated rats when compared to the controls [60,61]. Similarly, the in vivo regulatory role of TNFR p55 in Yersinia-induced arthritis in mice has been reported [62]. In another study, the exposure of eye-derived antigen-presenting cell (APC) to transforming growth factor $\beta$ (TGF $\beta$ ) resulted in increased expression of TNF $\alpha$ and TNFR2. This increase in expression was necessary in order to induce tolerance [63]. Furthermore, murine macrophages treated with TNF $\alpha$ produced less IL-23 and IL-12p70 after stimulation with IFN- $\gamma$ and lipopolysaccharide (LPS), thus reflecting the anti-inflammatory effect of TNF $\alpha$ [64]. On the basis of the above finding, it is conceivable that some patients treated with neutralizing antibodies against $\mathrm{TNF} \alpha$ (described above) might unexpectedly show aggravation of arthritis. This may occur if TNF $\alpha$ neutralization is performed under conditions that otherwise facilitate anti-inflammatory activity of endogenous TNF $\alpha$. In view of the dual role of TNF $\alpha$, above studies highlight that there is still much more to learn about the diverse functional attributes of these established cytokines in the pathogenesis of arthritis and other inflammatory disorders.

A new therapeutic approach based on cytokine inhibition is represented by active immunization as an alternative to passive immunization involving exogenous anti-cytokine antibodies $[65,66]$. Active immunization using synthetic peptides (epitope regions) of cytokines [67], recombinant cytokine containing T helper epitopes [68], or naked DNA [69] encoding the molecule have been shown to induce anti-cytokine antibodies, which can neutralize the cytokines produced in vivo. Active immunization strategies targeting the cytokines IL-1 $\beta$ [67], TNF $\alpha$ [68], and IL-23p19 [70], and the chemokine IFN-gamma-inducible protein 10 (IP-10) [69] have yielded promising results in animal models RA.

\section{The Use of Small Molecule Inhibitors of Cytokine Production for Controlling Inflammation}

A variety of natural inhibitors of cytokine signaling exist in the cells. These include members of the suppressor of cytokine signaling (SOCS), SH2-containing phosphatases (SHP), and the protein inhibitors of activated STATs (PIAS) families [71]. However, these inhibitors fail to effectively control chronic inflammation in patients with inflammatory diseases. Over the years, continuous efforts have been made to develop approaches that can prevent the production of a pro-inflammatory cytokine and thereby preempt subsequent cytokine-driven reactions and the resulting inflammation. Accordingly,

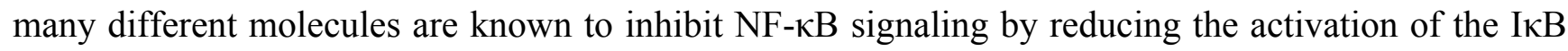
kinase (IKK) complex by binding to the ATP-binding site of IKK $\beta$ [72]. Another effective target for inhibition is the Januk kinase (JAK) pathway. The molecule CP-690550, which is now known by the name Tofacitinib, is a JAK3 inhibitor. Rats/mice treated with this drug showed a marked reduction in the incidence and severity of arthritis in the adjuvant arthritis (AA) and collagen-induced arthritis (CIA) models of RA [73]. Multiple phase III trials have been conducted using Tofacitinib in RA patients [74]. These trials demonstrated the safety and efficacy of Tofacitinib. However, there were some side effects associated with its use. For example, studies in the mouse models have revealed the likely risk of activating latent tuberculosis [75].

Likewise, Celastrol, a natural bioactive compound derived from Celastrus aculeatus Merr, inhibits NF- $\kappa B$ activation and STAT3 signaling leading to the inhibition of IL-17, IL-6, IL-1 $\beta$, TNF $\alpha$, and chemokines, which results in the suppression of AA in rats [76-78]. TAK-242 (or Resatorvid) is 
a small molecule that inhibits Toll-like receptor 4 (TLR4) signaling by binding selectively to TLR4 and inhibiting its ability to associate with its adaptor molecules [79]. This inhibition prevents cells from becoming activated and producing pro-inflammatory cytokines. There are many small molecule inhibitors of cytokine production being tested besides those mentioned above [80].

\section{Gene Therapy for Modulating Cytokine Response to Control Arthritis}

Gene therapy permits sustained expression of gene products at precise anatomical locations [81-84], and such approaches aimed at correcting the cytokine balance have been tested in experimental models of RA and patients with RA $[81,85,86]$. In these approaches, the genes encoding specific products with anti-arthritic activity are delivered into intra- or extra-articular sites using viral or non-viral vectors. The targeting of various cytokines via gene therapy is summarized in Table 2 followed by a description of the silencing of specific genes for the purpose of modulating cytokine responses:

\section{1. $I L-1 \beta$}

Various approaches have been developed to neutralize the effect of IL-1 $\beta$ by interleukin-1 receptor antagonist (IL-1Ra). Injection of recombinant adeno-associated virus vector encoding IL-1Ra (rAAV-IL-1Ra) complementary DNA [43] into the knee joint of rats was effective in producing optimal level of IL-1Ra locally and in suppressing arthritis in LPS-induced arthritis model. The IL-1Ra-encoding gene was among the first ones to be tested for potential use in a gene therapy clinical trial. In one study, the $I L-1 R a$ gene was delivered locally into the metacarpophalangeal joints of a postmenopausal woman to test gene expression and production of IL-1Ra ex vivo [44]. In another study, the synovial fibroblasts collected from two RA patients were first transduced with a retrovirus, MFG-IRAP, carrying the IL-1Ra transgene and then were injected back into the inflamed metacarpophalangeal joints. Both patients responded to that treatment with reduced pain and swelling, and one of the patients showed reduced matrix metalloproteinase-3 (MMP-3) and IL-1 $\beta$ expression in synovial tissue tested ex vivo [45].

\section{2. $T N F \alpha$}

Plasmids encoding soluble TNF $\alpha$ receptor (sTNFR) were transduced by electrotransfer and injected into mice with CIA. This treatment resulted in a decrease in both clinical and histological signs of the disease [46]. In another study in CIA, a similar treatment reduced clinical arthritis as well as IL-1 $\beta$ and IL-12 in the paws [47]. In a study in RA patients, the TNF $\alpha$ gene delivered using adeno-associated vector was found to be safe and well-tolerated [48].

\section{3. $I L-18$}

IL-18 is a pro-inflammatory cytokine that plays a role in the pathogenesis of RA $[87,88]$ and it offers another cytokine target for RA gene therapy. Injection of an adenoviral vector containing the murine IL-18-binding protein (IL-18BP) gene into mice with CIA resulted in significant reduction in inflammation and destruction of bone and cartilage [52]. 


\subsection{IFN- $\beta$}

IFN- $\beta$ possesses significant immunomodulatory properties and this cytokine has been considered for arthritis therapy $[49,89]$. Systemic administration of IFN- $\beta$ was effective in suppressing arthritis in mice and monkeys, but did not have much effect in RA patients [89]. Therefore, approaches using local IFN- $\beta$ treatment have been considered. In this regard, local IFN- $\beta$ production by adenovirus-mediated gene transfer into the ankle joints of rats with AA resulted in the inhibition of arthritis progression and protection against bone damage [49].

\subsection{IL-4 and IL-10}

Gene therapy approaches using anti-inflammatory cytokines have also been attempted for arthritis control. Injection of an adenoviral vector encoding the gene for human IL-4 into mice resulted in decreased production of the inflammatory cytokines IL-1 $\beta$ and TNF $\alpha$ [50]. Injection of lentiviral vectors expressing the IL-10 gene under inflammation-dependent promoters such as Saa3 and Mmp13 intra-articularly into knee joints of mice resulted in reduced synovitis and cartilage proteoglycan depletion in experimental arthritis [51].

\subsection{Small Interfering RNA (SiRNA)/Short Hairpin RNA (ShRNA)-Induced Cytokine Modulation for} Arthritis Therapy

RNA interference, particularly employing siRNA, is a widely used approach to achieve the silencing of the gene of interest. TNF $\alpha$ genes delivered via nanoparticles consisting of polymerized siRNA targeting TNF $\alpha$ complexed with thiolated glycol chitosan polymer significantly inhibited inflammation and bone erosion in mice with CIA [90]. In another study based on a special type of delivery vehicle called wrapsome (WS), siRNA-encapsulating liposomes were systemically administered into mice with CIA. It resulted in significant reduction in the severity of arthritis as well as TNF $\alpha$ mRNA level in the joints [91]. The siRNA thus delivered was targeted primarily to $\mathrm{CD}_{11} \mathrm{~b}^{+}$myeloid cells. Similarly, poly(lactic-co-glycolytic) acid (PLGA) nanoparticles coated with arginine-glycine-aspartate (RGD) peptide and encapsulating STAT1-targeting siRNAs were effective in suppressing arthritis via selective inhibition of macrophage and dendritic cell activation [92]. Examination of the paws revealed reduced mRNA for STAT1 but increased mRNA for IL-10, an immunomodulatory cytokine for arthritis. In another study, the T-bet shRNA recombinant plasmid ( $p$-T-shRNA), which was aimed at inhibiting T-bet, the transcription factor for Th1 cells, when delivered locally was effective in downregulating IFN- $\gamma$ and IL-17 [93]. Despite the success of experimental approaches, siRNA therapy has not advanced into the clinic as rapidly as was anticipated earlier, in part owing to the sequenceand target-independent suppression and off-target effects [94,95].

Additional approaches for gene therapy of arthritis have been explored, including antigen-induced tolerance [96,97]. Application of gene therapy to modulation of cytokines offers a new approach for the management of RA and other types of arthritis. Despite several notable advancements discussed above, the goal of using gene therapy for effective symptomatic relief in RA without the side effects is still elusive. A summary of six clinical trials initiated in RA is described elsewhere [82]; however, none of these advanced beyond phase I. Most concerns in gene therapy have focused on the adverse effects, 
both short-term and long-term, caused by the viral vectors used [82-84]. It has shown that viral vectors may possess the risk of inducing an immune response, of vector spreading to other tissues, and of causing insertional mutagenesis, oncogenic transformations and lymphoproliferative disorders [82-84,98,99]. In fact, gene therapy was subjected to heavy scrutiny since it became known that the viral vectors used in a clinical trial subsequently caused leukemia [34]. However, many of these concerns have been overcome by several advancements in the type of viral vectors being used in gene therapy and by the availability of refined non-viral vectors [82-84]. In addition to the above-mentioned risks, there are some ethical considerations for gene therapy. In the case of somatic cell gene therapy, the ethical concerns relate to the relative benefit/risk ratio, criteria for selection of patients for experimental therapy, ensuring voluntary participation, and maintaining privacy and confidentiality of the procedures [100]. In the case of germ-line gene therapy, there is an additional concern that this approach might become a tool for enhancement of specific genetic traits in otherwise healthy individuals [101]. Nevertheless, although gene therapy may currently pose some risks, with new advancements and ethical regulations, it can be harnessed for treatment of arthritis and other chronic, debilitating diseases.

\section{The Relatively Newer Cytokines (IL-32, IL-34 and IL-35) and Their Roles in Inflammation and Autoimmune Arthritis}

\subsection{IL-32}

The IL-32 gene has been identified in most mammals except rodents [102]. IL-32 is produced by synovium-infiltrating lymphocytes and synovial fibroblasts of arthritic joints. In RA, the levels of IL-32 correlated with the severity of the disease as well as with the expression of other pro-inflammatory cytokines, including TNF $\alpha$ and IL-1 $\beta$ [103-105]. IL-32 plays a critical role in the differentiation and activation of macrophages [106]. Furthermore, IL-32 cooperates with TNF $\alpha$ and IL-17 in facilitating increased production of other pro-inflammatory cytokines and chemokines leading to chronic inflammation and osteoclastic bone erosion in RA [107]. IL-32 induces the production of IL-17 in CD4 ${ }^{+} \mathrm{T}$ cells, and reciprocally IL-17 affects the expression of IL-32 in fibroblasts-like synoviocytes (FLSs) of RA patients [108]. The overexpression of human IL-32 $\beta$ and the adoptive transfer of $\mathrm{CD}^{+} \mathrm{T}$ cells expressing this cytokine into mice led to aggravation of CIA [104]. Furthermore, intra-articular injection of IL-32 into naïve mice or into mice with CIA caused joint swelling, migration of inflammatory cells into the joints, and cartilage damage [103,109]. These effects of IL-32 were significantly reduced or abrogated in mice deficient in TNF $\alpha$, indicating that some of the actions of IL-32 are TNF $\alpha$-dependent [103].

\section{2. $I L-34$}

IL-34 shows a functional association with macrophage colony stimulating factor (M-CSF) [110,111], and it has been implicated in macrophage differentiation and osteoclastogenesis [112-114]. In addition, injection of IL-34 into mice increases the number of osteoclast precursors and enhances bone resorption [112]. Other pro-inflammatory cytokines such as TNF $\alpha$ and IL-1 $\beta$ can stimulate IL-34 expression through the NF- $\mathrm{KB}$ and JNK pathway [115], whereas IL-34 can increase the production of IL-17 [116]. IL-34 is expressed in the synovium and fibroblast like synoviocytes (FLS) of RA patients. Increased levels of IL-34 have been reported in serum and synovial fluid of RA patients, and the levels 
of IL-34 correlate well with that of IL-6, receptor activator of nuclear factor kappa-B ligand (RANKL), rheumatoid factor (RF) and anti-cyclic citrullinated peptide antibody (ACPA) [117].

\section{3. $I L-35$}

IL-35 is a member of the IL-12 cytokine family [118,119]. IL-35 is an anti-inflammatory and immunosuppressive cytokine produced by natural $\mathrm{CD}^{+} \mathrm{Foxp}^{+}$regulatory $\mathrm{T}$ cells (nTreg). Interestingly, IL-35 can induce the differentiation of $\mathrm{CD}^{+}$effector $\mathrm{T}$ cells into a distinct subset of regulatory $\mathrm{T}$ cells, which in turn express IL-35 but do not express Foxp3, TGF- $\beta$ and IL-10 (iTreg35 cells) [118]. Furthermore, such iTreg35 cells can suppress experimental autoimmune encephalomyelitis (EAE) and inflammatory bowel disease (IBD) as tested in animal models [118]. This suppression by iTreg35 was mediated via IL-35. Other investigators have also reported that IL-35, either injected as exogenous IL-35 or expressed locally in vivo, can prevent experimental autoimmunity such as CIA, type 1 diabetes (T1D), and colitis [120-123]. The protective effect of IL-35 against CIA involved the expansion of $\mathrm{CD} 4{ }^{+} \mathrm{CD} 25^{+}$Foxp $3^{+}$Treg coupled with a reduction of IL-17 response but an increase in IFN- $\gamma$ production [120]. In another study, IL-35-induced suppression of CIA was associated with stimulation of $\mathrm{CD} 39^{+} \mathrm{CD} 4^{+} \mathrm{CD} 25^{-}$regulatory $\mathrm{T}$ cells and an increase in IL-10 production, combined with a reduction in IL-17, IFN- $\gamma$, and anti-CII antibodies [121]. However, a recent study highlighted the contradictory disease-aggravating effect of IL-35. In that study, IL-35 gene transfer resulted in aggravation of arthritis (CIA) and increased the ratio of Th17/Treg cells in the spleen of arthritic mice [124]. Studies in other models of autoimmunity revealed that local expression of IL-35 in pancreatic $\beta$-islets can suppress T1D in non-obese diabetic (NOD) mice [122], and that IL-35 treatment can suppress colitis [123]. Thus, additional studies are required to further clarify the pro- $v$ s. anti-inflammatory activity of IL-35.

As discussed above, some of the newer cytokines such as IL-32, IL-34 and IL-35 are being investigated for their role in the pathogenesis and treatment of arthritis. The predominantly pro-inflammatory members of this group can be targeted for their downmodulation, whereas the predominantly anti-inflammatory members of the group can be boosted for their therapeutic effects in arthritis. Various approaches, including antibody neutralization, gene therapy, transcriptional silencing, etc., which already have been tested with established cytokines, can be extended to these newer cytokines (Figure 2). It is hoped that continued advancements in ongoing approaches coupled with novel cytokine targets will have a significant impact on the management of arthritis in the very near future.

\section{Conclusions}

Pro-inflammatory cytokines, which drive the initiation and progression of autoimmune arthritis, are the prime therapeutic targets for this debilitating disease. The biologics based on neutralization of a few of the pro-inflammatory cytokines are already in the clinic and additional new ones are in clinical/preclinical trials. Gene therapy targeting these cytokines is also gaining momentum despite overall general decline in interest in this approach over the past decade or so. Furthermore, newer cytokines are on the horizon, some pro-inflammatory and others anti-inflammatory. It is hoped that one or more of these cytokine might offer a viable therapeutic target for arthritis therapy. Overall, most of the effort in cytokine-based therapy is focused on dampening pro-inflammatory cytokines. 
However, there are some promising leads for accentuation of the anti-inflammatory/immunoregulatory cytokines to control autoimmune arthritis. In conclusion, there is high optimism for the development of new arthritis therapies based on advances in basic science aspects of this disease in the coming years.

\section{Acknowledgments}

This work was supported in part by R01AT004321 grant from the National Institutes of Health (NIH)/NCCAM, Bethesda, MD, USA. We thank Brian Astry for helpful discussions.

\section{Author Contributions}

Shivaprasad H. Venkatesha, Steven Dudics, Bodhraj Acharya and Kamal D. Moudgil contributed to the conceptual design of the review article, to the writing of the article, to the construction of tables and figures, and to the editing and proofreading of the article. Steven Dudics and Bodhraj Acharya contributed equally to this manuscript.

\section{Conflicts of Interest}

The authors declare no conflict of interest.

\section{References}

1. Astry, B.; Harberts, E.; Moudgil, K.D. A cytokine-centric view of the pathogenesis and treatment of autoimmune arthritis. J. Interferon Cytokine Res. 2011, 31, 927-940.

2. Clavel, G.; Thiolat, A.; Boissier, M.C. Interleukin newcomers creating new numbers in rheumatology: IL-34 to IL-38. Jt. Bone Spine 2013, 80, 449-453.

3. Leng, R.X.; Pan, H.F.; Tao, J.H.; Ye, D.Q. IL-19, IL-20 and IL-24: Potential therapeutic targets for autoimmune diseases. Expert Opin. Ther. Targets 2011, 15, 119-126.

4. Garlanda, C.; Dinarello, C.A.; Mantovani, A. The interleukin-1 family: Back to the future. Immunity 2013, 39, 1003-1018.

5. Gaffen, S.L.; Jain, R.; Garg, A.V.; Cua, D.J. The IL-23-IL-17 immune axis: From mechanisms to therapeutic testing. Nat. Rev. Immunol. 2014, 14, 585-600.

6. Tang, C.; Chen, S.; Qian, H.; Huang, W. Interleukin-23: As a drug target for autoimmune inflammatory diseases. Immunology 2012, 135, 112-124.

7. Bettelli, E.; Korn, T.; Kuchroo, V.K. Th17: The third member of the effector T cell trilogy. Curr. Opin. Immunol. 2007, 19, 652-657.

8. Rajaiah, R.; Puttabyatappa, M.; Polumuri, S.K.; Moudgil, K.D. Interleukin-27 and interferon- $\gamma$ are involved in regulation of autoimmune arthritis. J. Biol. Chem. 2011, 286, 2817-2825.

9. Adamopoulos, I.E.; Pflanz, S. The emerging role of interleukin 27 in inflammatory arthritis and bone destruction. Cytokine Growth Factor Rev. 2013, 24, 115-121.

10. Clark, I.A. How TNF was recognized as a key mechanism of disease. Cytokine Growth Factor Rev. 2007, 18, 335-343. 
11. Walsh, L.J.; Trinchieri, G.; Waldorf, H.A.; Whitaker, D.; Murphy, G.F. Human dermal mast cells contain and release tumor necrosis factor alpha, which induces endothelial leukocyte adhesion molecule 1. Proc. Natl. Acad. Sci. USA 1991, 88, 4220-4224.

12. Wajant, H.; Pfizenmaier, K.; Scheurich, P. Tumor necrosis factor signaling. Cell Death Differ. 2003, 10, 45-65.

13. Locksley, R.M.; Killeen, N.; Lenardo, M.J. The TNF and TNF receptor superfamilies: Integrating mammalian biology. Cell 2001, 104, 487-501.

14. Chen, G.; Goeddel, D.V. TNF-R1 signaling: A beautiful pathway. Science 2002, 296, 1634-1635.

15. Kant, S.; Swat, W.; Zhang, S.; Zhang, Z.-Y.; Neel, B.G.; Flavell, R.A.; Davis, R.J. TNF-stimulated MAP kinase activation mediated by a RHO family gtpase signaling pathway. Genes Dev. 2011, 25, 2069-2078.

16. Hot, A.; Miossec, P. Effects of interleukin (IL)-17a and IL-17F in human rheumatoid arthritis synoviocytes. Ann. Rheum. Dis. 2011, 70, 727-732.

17. Shabgah, A.G.; Fattahi, E.; Shahneh, F.Z. Interleukin-17 in human inflammatory diseases. Postep. Dermatol. Alergol. 2014, 31, 256-261.

18. Sarkar, S.; Justa, S.; Brucks, M.; Endres, J.; Fox, D.A.; Zhou, X.; Alnaimat, F.; Whitaker, B.; Wheeler, J.C.; Jones, B.H.; et al. Interleukin (IL)-17a, $\mathrm{f}$ and af in inflammation: A study in collagen-induced arthritis and rheumatoid arthritis. Clin. Exp. Immunol. 2014, 177, 652-661.

19. Mertens, M.; Singh, J.A. Anakinra for rheumatoid arthritis: A systematic review. J. Rheumatol. 2009, 36, 1118-1125.

20. Goh, A.X.; Bertin-Maghit, S.; Ping Yeo, S.; Ho, A.W.; Derks, H.; Mortellaro, A.; Wang, C.I. A novel human anti-interleukin-1beta neutralizing monoclonal antibody showing in vivo efficacy. MAbs 2014, 6, 765-773.

21. Chakraborty, A.; Tannenbaum, S.; Rordorf, C.; Lowe, P.J.; Floch, D.; Gram, H.; Roy, S. Pharmacokinetic and pharmacodynamic properties of canakinumab, a human anti-interleukin-1 $\beta$ monoclonal antibody. Clin. Pharmacokinet. 2012, 51, e1-e18.

22. Geiler, J.; McDermott, M.F. Gevokizumab, an anti-IL-1 $\beta$ MAB for the potential treatment of type 1 and 2 diabetes, rheumatoid arthritis and cardiovascular disease. Curr. Opin. Mol. Ther. 2010, 12, 755-769.

23. Bihorel, S.; Fiedler-Kelly, J.; Ludwig, E.; Sloan-Lancaster, J.; Raddad, E. Population pharmacokinetic modeling of ly2189102 after multiple intravenous and subcutaneous administrations. AAPS J. 2014, 16, 1009-1017.

24. McDermott, M.F. Rilonacept in the treatment of chronic inflammatory disorders. Drugs Today 2009, 45, 423-430.

25. Liang, B.; Gardner, D.B.; Griswold, D.E.; Bugelski, P.J.; Song, X.Y. Anti-interleukin-6 monoclonal antibody inhibits autoimmune responses in a murine model of systemic lupus erythematosus. Immunology 2006, 119, 296-305.

26. LaSpina, M.; Tripathi, S.; Gatto, L.A.; Bruch, D.; Maier, K.G.; Kittur, D.S. An interleukin-6-neutralizing antibody prevents cyclosporine-induced nephrotoxicity in mice. J. Surg. Res. 2008, 148, 121-125. 
27. Straub, R.H.; Harle, P.; Yamana, S.; Matsuda, T.; Takasugi, K.; Kishimoto, T.; Nishimoto, N. Anti-interleukin-6 receptor antibody therapy favors adrenal androgen secretion in patients with rheumatoid arthritis: A randomized, double-blind, placebo-controlled study. Arthritis Rheumatol. 2006, 54, 1778-1785.

28. Semerano, L.; Thiolat, A.; Minichiello, E.; Clavel, G.; Bessis, N.; Boissier, M.C. Targeting IL-6 for the treatment of rheumatoid arthritis: Phase ii investigational drugs. Expert Opin. Investig. Drugs 2014, 23, 979-999.

29. Nishimoto, N.; Kishimoto, T.; Yoshizaki, K. Anti-interleukin 6 receptor antibody treatment in rheumatic disease. Ann. Rheum. Dis. 2000, 59 (Suppl. S1), i21-i27.

30. Lou, H.; Zong, Y.; Ge, Y.R.; Cheng, J.W.; Wei, R.L. Efficacy and tolerability of latanoprost compared with timolol in the treatment of patients with chronic angle-closure glaucoma. Curr. Med. Res. Opin. 2014, 30, 1367-1373.

31. St Clair, E.W.; van der Heijde, D.M.; Smolen, J.S.; Maini, R.N.; Bathon, J.M.; Emery, P.; Keystone, E.; Schiff, M.; Kalden, J.R.; Wang, B.; et al. Combination of infliximab and methotrexate therapy for early rheumatoid arthritis: A randomized, controlled trial. Arthritis Rheumatol. 2004, 50, 3432-3443.

32. Wiens, A.; Correr, C.J.; Venson, R.; Otuki, M.F.; Pontarolo, R. A systematic review and meta-analysis of the efficacy and safety of adalimumab for treating rheumatoid arthritis. Rheumatol. Int. 2010, 30, 1063-1070.

33. Moreland, L.W.; Baumgartner, S.W.; Schiff, M.H.; Tindall, E.A.; Fleischmann, R.M.; Weaver, A.L.; Ettlinger, R.E.; Cohen, S.; Koopman, W.J.; Mohler, K.; et al. Treatment of rheumatoid arthritis with a recombinant human tumor necrosis factor receptor (p75)-fc fusion protein. N. Engl. J. Med. 1997, 337, 141-147.

34. Keystone, E.C.; Genovese, M.C.; Klareskog, L.; Hsia, E.C.; Hall, S.T.; Miranda, P.C.; Pazdur, J.; Bae, S.C.; Palmer, W.; Zrubek, J.; et al. Golimumab, a human antibody to tumour necrosis factor $\alpha$ given by monthly subcutaneous injections, in active rheumatoid arthritis despite methotrexate therapy: The GO-FORWARD study. Ann. Rheum. Dis. 2009, 68, 789-796.

35. Langley, R.G.; Elewski, B.E.; Lebwohl, M.; Reich, K.; Griffiths, C.E.; Papp, K.; Puig, L.; Nakagawa, H.; Spelman, L.; Sigurgeirsson, B.; et al. Secukinumab in plaque psoriasis-Results of two phase 3 trials. N. Engl. J. Med. 2014, 371, 326-338.

36. Patel, D.D.; Lee, D.M.; Kolbinger, F.; Antoni, C. Effect of IL-17a blockade with secukinumab in autoimmune diseases. Ann. Rheum. Dis. 2013, 72 (Suppl. S2), ii116-ii123.

37. Leonardi, C.; Matheson, R.; Zachariae, C.; Cameron, G.; Li, L.; Edson-Heredia, E.; Braun, D.; Banerjee, S. Anti-interleukin-17 monoclonal antibody ixekizumab in chronic plaque psoriasis. N. Engl. J. Med. 2012, 366, 1190-1199.

38. Mease, P.J.; Genovese, M.C.; Greenwald, M.W.; Ritchlin, C.T.; Beaulieu, A.D.; Deodhar, A.; Newmark, R.; Feng, J.; Erondu, N.; Nirula, A. Brodalumab, an anti-IL17RA monoclonal antibody, in psoriatic arthritis. N. Engl. J. Med. 2014, 370, 2295-2306.

39. Sandborn, W.J.; Gasink, C.; Gao, L.L.; Blank, M.A.; Johanns, J.; Guzzo, C.; Sands, B.E.; Hanauer, S.B.; Targan, S.; Rutgeerts, P.; et al. Ustekinumab induction and maintenance therapy in refractory crohn's disease. N. Engl. J. Med. 2012, 367, 1519-1528. 
40. Sofen, H.; Smith, S.; Matheson, R.T.; Leonardi, C.L.; Calderon, C.; Brodmerkel, C.; Li, K.; Campbell, K.; Marciniak, S.J., Jr.; Wasfi, Y.; et al. Guselkumab (an IL-23-specific mab) demonstrates clinical and molecular response in patients with moderate-to-severe psoriasis. J. Allergy Clin. Immunol. 2014, 133, 1032-1040.

41. Yoshida, Y.; Tanaka, T. Interleukin 6 and rheumatoid arthritis. BioMed Res. Int. 2014, 2014, doi:10.1155/2014/698313.

42. Calabrese, L.H.; Rose-John, S. IL-6 biology: Implications for clinical targeting in rheumatic disease. Nat. Rev. 2014, 10, 720-727.

43. Pan, R.Y.; Chen, S.L.; Xiao, X.; Liu, D.W.; Peng, H.J.; Tsao, Y.P. Therapy and prevention of arthritis by recombinant adeno-associated virus vector with delivery of interleukin-1 receptor antagonist. Arthritis Rheumatol. 2000, 43, 289-297.

44. Evans, C.H.; Ghivizzani, S.C.; Herndon, J.H.; Wasko, M.C.; Reinecke, J.; Wehling, P.; Robbins, P.D. Clinical trials in the gene therapy of arthritis. Clin. Orthop. Relat. Res. 2000, 379, S300-S307.

45. Wehling, P.; Reinecke, J.; Baltzer, A.W.; Granrath, M.; Schulitz, K.P.; Schultz, C.; Krauspe, R.; Whiteside, T.W.; Elder, E.; Ghivizzani, S.C.; et al. Clinical responses to gene therapy in joints of two subjects with rheumatoid arthritis. Hum. Gene Ther. 2009, 20, 97-101.

46. Bloquel, C.; Bessis, N.; Boissier, M.C.; Scherman, D.; Bigey, P. Gene therapy of collagen-induced arthritis by electrotransfer of human tumor necrosis factor- $\alpha$ soluble receptor I variants. Hum. Gene Ther. 2004, 15, 189-201.

47. Kim, J.M.; Ho, S.H.; Hahn, W.; Jeong, J.G.; Park, E.J.; Lee, H.J.; Yu, S.S.; Lee, C.S.; Lee, Y.W.; Kim, S. Electro-gene therapy of collagen-induced arthritis by using an expression plasmid for the soluble p75 tumor necrosis factor receptor-Fc fusion protein. Gene Ther. 2003, 10, 1216-1224.

48. Mease, P.J.; Hobbs, K.; Chalmers, A.; El-Gabalawy, H.; Bookman, A.; Keystone, E.; Furst, D.E.; Anklesaria, P.; Heald, A.E. Local delivery of a recombinant adenoassociated vector containing a tumour necrosis factor alpha antagonist gene in inflammatory arthritis: A phase 1 dose-escalation safety and tolerability study. Ann. Rheum. Dis. 2009, 68, 1247-1254.

49. Adriaansen, J.; Kuhlman, R.R.; van Holten, J.; Kaynor, C.; Vervoordeldonk, M.J.; Tak, P.P. Intraarticular interferon-beta gene therapy ameliorates adjuvant arthritis in rats. Hum. Gene Ther. 2006, 17, 985-996.

50. Woods, J.M.; Tokuhira, M.; Berry, J.C.; Katschke, K.J., Jr.; Kurata, H.; Damergis, J.A., Jr.; Arai, K.; Koch, A.E. Interleukin-4 adenoviral gene therapy reduces production of inflammatory cytokines and prostaglandin e 2 by rheumatoid arthritis synovium ex vivo. J. Investig. Med. 1999, 47, 285-292.

51. Vermeij, E.A.; Broeren, M.G.; Bennink, M.B.; Arntz, O.J.; Gjertsson, I.; van Lent P, L.E.M.; van den Berg, W.B.; Koenders, M.I.; van de Loo, F.A. Disease-regulated local IL-10 gene therapy diminishes synovitis and cartilage proteoglycan depletion in experimental arthritis. Ann. Rheum. Dis. 2014, doi:10.1136/annrheumdis-2014-205223.

52. Smeets, R.L.; van de Loo, F.A.; Arntz, O.J.; Bennink, M.B.; Joosten, L.A.; van den Berg, W.B. Adenoviral delivery of IL-18 binding protein c ameliorates collagen-induced arthritis in mice. Gene Ther. 2003, 10, 1004-1011. 
53. Brennan, F.M.; McInnes, I.B. Evidence that cytokines play a role in rheumatoid arthritis. J. Clin. Investig. 2008, 118, 3537-3545.

54. Singh, R.P.; Hasan, S.; Sharma, S.; Nagra, S.; Yamaguchi, D.T.; Wong, D.; Bh, H.; Hossain, A. Th17 cells in inflammation and autoimmunity. Autoimmun. Rev. 2014, 13, 1174-1181.

55. Shetty, A.; Hanson, R.; Korsten, P.; Shawagfeh, M.; Arami, S.; Volkov, S.; Vila, O.; Swedler, W.; Shunaigat, A.N.; Smadi, S.; et al. Tocilizumab in the treatment of rheumatoid arthritis and beyond. Drug Des. Dev. Ther. 2014, 8, 349-364.

56. Alghasham, A.; Rasheed, Z. Therapeutic targets for rheumatoid arthritis: Progress and promises. Autoimmunity 2014, 47, 77-94.

57. Bongartz, T.; Sutton, A.J.; Sweeting, M.J.; Buchan, I.; Matteson, E.L.; Montori, V. Anti-TNF antibody therapy in rheumatoid arthritis and the risk of serious infections and malignancies: Systematic review and meta-analysis of rare harmful effects in randomized controlled trials. JAMA 2006, 295, 2275-2285.

58. Cantini, F.; Niccoli, L.; Goletti, D. Tuberculosis risk in patients treated with non-anti-tumor necrosis factor-alpha (TNF- $\alpha$ ) targeted biologics and recently licensed TNF- $\alpha$ inhibitors: Data from clinical trials and national registries. J. Rheumatol. Suppl. 2014, 91, 56-64.

59. Choy, E.H.; Kavanaugh, A.F.; Jones, S.A. The problem of choice: Current biologic agents and future prospects in RA. Nat. Rev. Rheumatol. 2013, 9, 154-163.

60. Kim, E.Y.; Chi, H.H.; Rajaiah, R.; Moudgil, K.D. Exogenous tumour necrosis factor alpha induces suppression of autoimmune arthritis. Arthritis Res. Ther. 2008, 10, R38.

61. Williams, R.O. Paradoxical effects of tumour necrosis factor- $\alpha$ in adjuvant-induced arthritis. Arthritis Res. Ther. 2008, 10, 113.

62. Elicabe, R.J.; Cargnelutti, E.; Serer, M.I.; Stege, P.W.; Valdez, S.R.; Toscano, M.A.; Rabinovich, G.A.; Di Genaro, M.S. Lack of TNFR p55 results in heightened expression of IFN- $\gamma$ and IL-17 during the development of reactive arthritis. J. Immunol. 2010, 185, 4485-4495.

63. Masli, S.; Turpie, B. Anti-inflammatory effects of tumour necrosis factor (TNF)- $\alpha$ are mediated via TNF-R2 (p75) in tolerogenic transforming growth factor- $\beta$-treated antigen-presenting cells. Immunology 2009, 127, 62-72.

64. Zakharova, M.; Ziegler, H.K. Paradoxical anti-inflammatory actions of TNF- $\alpha$ : Inhibition of IL-12 and IL-23 via TNF receptor 1 in macrophages and dendritic cells. J. Immunol. 2005, 175, 5024-5033.

65. Zagury, D.; Burny, A.; Gallo, R.C. Toward a new generation of vaccines: The anti-cytokine therapeutic vaccines. Proc. Natl. Acad. Sci. USA 2001, 98, 8024-8029.

66. Spohn, G.; Keller, I.; Beck, M.; Grest, P.; Jennings, G.T.; Bachmann, M.F. Active immunization with IL-1 displayed on virus-like particles protects from autoimmune arthritis. Eur. J. Immunol. 2008, 38, 877-887.

67. Bertin-Maghit, S.M.; Capini, C.J.; Bessis, N.; Chomilier, J.; Muller, S.; Abbas, A.; Autin, L.; Spadoni, J.L.; Rappaport, J.; Therwath, A.; et al. Improvement of collagen-induced arthritis by active immunization against murine IL-1 $\beta$ peptides designed by molecular modelling. Vaccine 2005, 23, 4228-4235. 
68. Dalum, I.; Butler, D.M.; Jensen, M.R.; Hindersson, P.; Steinaa, L.; Waterston, A.M.; Grell, S.N.; Feldmann, M.; Elsner, H.I.; Mouritsen, S. Therapeutic antibodies elicited by immunization against TNF- $\alpha$. Nat. Biotechnol. 1999, 17, 666-669.

69. Salomon, I.; Netzer, N.; Wildbaum, G.; Schif-Zuck, S.; Maor, G.; Karin, N. Targeting the function of IFN- $\gamma$-inducible protein 10 suppresses ongoing adjuvant arthritis. J. Immunol. 2002, 169, 2685-2693.

70. Ratsimandresy, R.A.; Duvallet, E.; Assier, E.; Semerano, L.; Delavallee, L.; Bessis, N.; Zagury, J.F.; Boissier, M.C. Active immunization against IL-23p19 improves experimental arthritis. Vaccine 2011, 29, 9329-9336.

71. Hilton, S.W.D.J. Inhibitors of cytokine signal transduction. J. Biol. Chem. 2004, 279, 821-824.

72. Gaestel, M.; Mengel, A.; Bothe, U.; Asadullah, K. Protein kinases as small molecule inhibitor targets in inflammation. Curr. Med. Chem. 2007, 14, 2214-2234.

73. Milici, A.J.; Kudlacz, E.M.; Audoly, L.; Zwillich, S.; Changelian, P. Cartilage preservation by inhibition of janus kinase 3 in two rodent models of rheumatoid arthritis. Arthritis Res. Ther. 2008, 10, R14.

74. Lundquist, L.M.; Cole, S.W.; Sikes, M.L. Efficacy and safety of tofacitinib for treatment of rheumatoid arthritis. World J. Orthop. 2014, 5, 504-511.

75. Maiga, M.; Lun, S.; Guo, H.; Winglee, K.; Ammerman, N.C.; Bishai, W.R. Risk of tuberculosis reactivation with tofacitinib (cp-690550). J. Infect. Dis. 2012, 205, 1705-1708.

76. Venkatesha, S.H.; Berman, B.M.; Moudgil, K.D. Herbal medicinal products target defined biochemical and molecular mediators of inflammatory autoimmune arthritis. Bioorg. Med. Chem. 2011, 19, 21-29.

77. Nanjundaiah, S.M.; Venkatesha, S.H.; Yu, H.; Tong, L.; Stains, J.P.; Moudgil, K.D. Celastrus and its bioactive celastrol protect against bone damage in autoimmune arthritis by modulating osteoimmune cross-talk. J. Biol. Chem. 2012, 287, 22216-22226.

78. Venkatesha, S.H.; Astry, B.; Nanjundaiah, S.M.; Yu, H.; Moudgil, K.D. Suppression of autoimmune arthritis by celastrus-derived celastrol through modulation of pro-inflammatory chemokines. Bioorg. Med. Chem. 2012, 20, 5229-5234.

79. Matsunaga, N.; Tsuchimori, N.; Matsumoto, T.; Ii, M. Tak-242 (resatorvid), a small-molecule inhibitor of toll-like receptor (TLR) 4 signaling, binds selectively to TLR4 and interferes with interactions between TLR4 and its adaptor molecules. Mol. Pharmacol. 2010, 79, 34-41.

80. McCormack, W.J.; Parker, A.E.; O’Neill, L.A. Toll-like receptors and nod-like receptors in rheumatic diseases. Arthritis Res. Ther. 2009, 11, 243.

81. Evans, C.H.; Ghivizzani, S.C.; Robbins, P.D. Getting arthritis gene therapy into the clinic. Nat. Rev. 2011, 7, 244-249.

82. Jorgensen, C.; Apparailly, F. Prospects for gene therapy in inflammatory arthritis. Best Pract. Res. 2010, 24, 541-552.

83. Nakasato, M.; Nonomura, Y.; Miyasaka, N.; Kohsaka, H. The gene delivery system for rheumatoid synovium. Jpn. J. Clin. Immunol. 2008, 31, 17-22.

84. Traister, R.S.; Hirsch, R. Gene therapy for arthritis. Mod. Rheumatol. 2008, 18, 2-14. 
85. Woods, A.M.; Thompson, S.J.; Wooley, P.H.; Panayi, G.; Klavinskis, L.S. Immune modulation of collagen-induced arthritis by intranasal cytokine gene delivery: A model for the therapy of rheumatoid arthritis. Arthritis Rheumatol. 2005, 52, 3761-3771.

86. Schmidt-Weber, C.B.; Pohlers, D.; Siegling, A.; Schadlich, H.; Buchner, E.; Volk, H.D.; Palombo-Kinne, E.; Emmrich, F.; Kinne, R.W. Cytokine gene activation in synovial membrane, regional lymph nodes, and spleen during the course of rat adjuvant arthritis. Cell Immunol. 1999, 195, 53-65.

87. Ji, J.D.; Lee, W.J. Interleukin-18 gene polymorphisms and rheumatoid arthritis: A meta-analysis. Gene 2013, 523, 27-32.

88. Zhang, W.; Cong, X.L.; Qin, Y.H.; He, Z.W.; He, D.Y.; Dai, S.M. IL-18 upregulates the production of key regulators of osteoclastogenesis from fibroblast-like synoviocytes in rheumatoid arthritis. Inflammation 2013, 36, 103-109.

89. Tak, P.P. IFN- $\beta$ in rheumatoid arthritis. Front. Biosci. 2004, 9, 3242-3247.

90. Lee, S.J.; Lee, A.; Hwang, S.R.; Park, J.S.; Jang, J.; Huh, M.S.; Jo, D.G.; Yoon, S.Y.; Byun, Y.; Kim, S.H.; et al. TNF- $\alpha$ gene silencing using polymerized sirna/thiolated glycol chitosan nanoparticles for rheumatoid arthritis. Mol. Ther. 2014, 22, 397-408.

91. Komano, Y.; Yagi, N.; Onoue, I.; Kaneko, K.; Miyasaka, N.; Nanki, T. Arthritic joint-targeting small interfering RNA-encapsulated liposome: Implication for treatment strategy for rheumatoid arthritis. J. Pharmacol. Exp. Ther. 2012, 340, 109-113.

92. Scheinman, R.I.; Trivedi, R.; Vermillion, S.; Kompella, U.B. Functionalized STAT1 siRNA nanoparticles regress rheumatoid arthritis in a mouse model. Nanomedicine 2011, 6, 1669-1682.

93. Xue, Y.; Yang, Y.; Su, Z.; Barnie, P.A.; Zheng, D.; Zhang, Y.; Xu, Y.; Wang, S.; Xu, H. Local delivery of T-bet shRNA reduces inflammation in collagen II-induced arthritis via downregulation of IFN- $\gamma$ and IL-17. Mol. Med. Rep. 2014, 9, 899-903.

94. Fedorov, Y.; Anderson, E.M.; Birmingham, A.; Reynolds, A.; Karpilow, J.; Robinson, K.; Leake, D.; Marshall, W.S.; Khvorova, A. Off-target effects by sirna can induce toxic phenotype. RNA 2006, 12, 1188-1196.

95. Kleinman, M.E.; Yamada, K.; Takeda, A.; Chandrasekaran, V.; Nozaki, M.; Baffi, J.Z.; Albuquerque, R.J.; Yamasaki, S.; Itaya, M.; Pan, Y.; et al. Sequence- and target-independent angiogenesis suppression by sirna via TLR3. Nature 2008, 452, 591-597.

96. Satpute, S.R.; Durai, M.; Moudgil, K.D. Antigen-specific tolerogenic and immunomodulatory strategies for the treatment of autoimmune arthritis. Semin. Arthritis Rheum. 2008, 38, 195-207.

97. Satpute, S.R.; Soukhareva, N.; Scott, D.W.; Moudgil, K.D. Mycobacterial Hsp65-IgG-expressing tolerogenic B cells confer protection against adjuvant-induced arthritis in Lewis rats. Arthritis Rheumatol. 2007, 56, 1490-1496.

98. Thomas, C.E.; Ehrhardt, A.; Kay, M.A. Progress and problems with the use of viral vectors for gene therapy. Nat. Rev. Genet. 2003, 4, 346-358.

99. Williams, D.A.; Thrasher, A.J. Concise review: Lessons learned from clinical trials of gene therapy in monogenic immunodeficiency diseases. Stem Cells Transl. Med. 2014, 3, 636-642.

100. Sade, R.M.; Khushf, G. Gene therapy: Ethical and social issues. J. South Carol. Med. Assoc. 1998, 94, 406-410. 
101. Wivel, N.A.; Walters, L. Germ-line gene modification and disease prevention: Some medical and ethical perspectives. Science 1993, 262, 533-538.

102. Kim, S. Interleukin-32 in inflammatory autoimmune diseases. Immune Netw. 2014, 14, 123-127.

103. Joosten, L.A.; Netea, M.G.; Kim, S.H.; Yoon, D.Y.; Oppers-Walgreen, B.; Radstake, T.R.; Barrera, P.; van de Loo, F.A.; Dinarello, C.A.; van den Berg, W.B. Il-32, a proinflammatory cytokine in rheumatoid arthritis. Proc. Natl. Acad. Sci. USA 2006, 103, 3298-3303.

104. Shoda, H.; Fujio, K.; Yamaguchi, Y.; Okamoto, A.; Sawada, T.; Kochi, Y.; Yamamoto, K. Interactions between IL-32 and tumor necrosis factor alpha contribute to the exacerbation of immune-inflammatory diseases. Arthritis Res. Ther. 2006, 8, R166.

105. Alsaleh, G.; Sparsa, L.; Chatelus, E.; Ehlinger, M.; Gottenberg, J.E.; Wachsmann, D.; Sibilia, J. Innate immunity triggers IL-32 expression by fibroblast-like synoviocytes in rheumatoid arthritis. Arthritis Res. Ther. 2010, 12, R135.

106. Jeong, H.J.; Nam, S.Y.; Oh, H.A.; Han, N.R.; Kim, Y.S.; Moon, P.D.; Shin, S.Y.; Kim, M.H.; Kim, H.M. Interleukin-32-induced thymic stromal lymphopoietin plays a critical role in macrophage differentiation through the activation of caspase-1 in vitro. Arthritis Res. Ther. 2012, 14, R259.

107. Son, M.H.; Jung, M.Y.; Choi, S.; Cho, D.; Kim, T.S. IL-32 $\gamma$ induces chemotaxis of activated t cells via dendritic cell-derived ccl5. Biochem. Biophys. Res. Commun. 2014, 450, 30-35.

108. Moon, Y.M.; Yoon, B.Y.; Her, Y.M.; Oh, H.J.; Lee, J.S.; Kim, K.W.; Lee, S.Y.; Woo, Y.J.; Park, K.S.; Park, S.H.; et al. IL-32 and IL-17 interact and have the potential to aggravate osteoclastogenesis in rheumatoid arthritis. Arthritis Res. Ther. 2012, 14, R246.

109. Dinarello, C.A.; Kim, S.H. IL-32, a novel cytokine with a possible role in disease. Ann. Rheum. Dis. 2006, 65 (Suppl. S3), iii61-iii64.

110. Bostrom, E.A.; Lundberg, P. The newly discovered cytokine IL-34 is expressed in gingival fibroblasts, shows enhanced expression by pro-inflammatory cytokines, and stimulates osteoclast differentiation. PLoS One 2013, 8, e81665.

111. Hwang, S.J.; Choi, B.; Kang, S.S.; Chang, J.H.; Kim, Y.G.; Chung, Y.H.; Sohn, D.H.; So, M.W.; Lee, C.K.; Robinson, W.H.; et al. Interleukin-34 produced by human fibroblast-like synovial cells in rheumatoid arthritis supports osteoclastogenesis. Arthritis Res. Ther. 2012, 14, R14.

112. Chen, Z.; Buki, K.; Vaaraniemi, J.; Gu, G.; Vaananen, H.K. The critical role of IL-34 in osteoclastogenesis. PLoS One 2011, 6, e18689.

113. Baud'huin, M.; Renault, R.; Charrier, C.; Riet, A.; Moreau, A.; Brion, R.; Gouin, F.; Duplomb, L.; Heymann, D. Interleukin-34 is expressed by giant cell tumours of bone and plays a key role in rankl-induced osteoclastogenesis. J. Pathol. 2010, 221, 77-86.

114. Chang, S.H.; Choi, B.Y.; Choi, J.; Yoo, J.J.; Ha, Y.J.; Cho, H.J.; Kang, E.H.; Song, Y.W.; Lee, Y.J. Baseline serum interleukin-34 levels independently predict radiographic progression in patients with rheumatoid arthritis. Rheumatol. Int. 2014, doi:10.1007/s00296-014-3056-5.

115. Chemel, M.; Le Goff, B.; Brion, R.; Cozic, C.; Berreur, M.; Amiaud, J.; Bougras, G.; Touchais, S.; Blanchard, F.; Heymann, M.F.; et al. Interleukin 34 expression is associated with synovitis severity in rheumatoid arthritis patients. Ann. Rheum. Dis. 2012, 71, 150-154.

116. Tian, Y.; Shen, H.; Xia, L.; Lu, J. Elevated serum and synovial fluid levels of interleukin-34 in rheumatoid arthritis: Possible association with disease progression via interleukin-17 production. J. Interferon Cytokine Res. 2013, 33, 398-401. 
117. Moon, S.J.; Hong, Y.S.; Ju, J.H.; Kwok, S.K.; Park, S.H.; Min, J.K. Increased levels of interleukin 34 in serum and synovial fluid are associated with rheumatoid factor and anticyclic citrullinated peptide antibody titers in patients with rheumatoid arthritis. J. Rheumatol. 2013, 40, 1842-1849.

118. Collison, L.W.; Chaturvedi, V.; Henderson, A.L.; Giacomin, P.R.; Guy, C.; Bankoti, J.; Finkelstein, D.; Forbes, K.; Workman, C.J.; Brown, S.A.; et al. IL-35-mediated induction of a potent regulatory t cell population. Nat. Immunol. 2010, 11, 1093-1101.

119. Collison, L.W.; Delgoffe, G.M.; Guy, C.S.; Vignali, K.M.; Chaturvedi, V.; Fairweather, D.; Satoskar, A.R.; Garcia, K.C.; Hunter, C.A.; Drake, C.G.; et al. The composition and signaling of the IL-35 receptor are unconventional. Nat. Immunol. 2012, 13, 290-299.

120. Niedbala, W.; Wei, X.Q.; Cai, B.; Hueber, A.J.; Leung, B.P.; McInnes, I.B.; Liew, F.Y. IL-35 is a novel cytokine with therapeutic effects against collagen-induced arthritis through the expansion of regulatory T cells and suppression of th17 cells. Eur. J. Immunol. 2007, 37, 3021-3029.

121. Kochetkova, I.; Golden, S.; Holderness, K.; Callis, G.; Pascual, D.W. IL-35 stimulation of ${\mathrm{CD} 39^{+}}^{+}$regulatory $\mathrm{T}$ cells confers protection against collagen II-induced arthritis via the production of IL-10. J. Immunol. 2010, 184, 7144-7153.

122. Bettini, M.; Castellaw, A.H.; Lennon, G.P.; Burton, A.R.; Vignali, D.A. Prevention of autoimmune diabetes by ectopic pancreatic beta-cell expression of interleukin-35. Diabetes 2012, 61, 1519-1526.

123. Wirtz, S.; Billmeier, U.; McHedlidze, T.; Blumberg, R.S.; Neurath, M.F. Interleukin-35 mediates mucosal immune responses that protect against T-cell-dependent colitis. Gastroenterology 2011, 141, 1875-1886.

124. Thiolat, A.; Denys, A.; Petit, M.; Biton, J.; Lemeiter, D.; Herve, R.; Lutomski, D.; Boissier, M.C.; Bessis, N. Interleukin-35 gene therapy exacerbates experimental rheumatoid arthritis in mice. Cytokine 2014, 69, 87-93.

(C) 2014 by the authors; licensee MDPI, Basel, Switzerland. This article is an open access article distributed under the terms and conditions of the Creative Commons Attribution license (http://creativecommons.org/licenses/by/4.0/). 